\title{
Analiza utjecaja oblika vlasništva na zaposlenost u Hrvatskoj
}

\section{Analysis of the ownership type effects on employment in Croatia}

\section{Sažetak}

U javnom diskursu tranzicijskih ekonomija, kao i u znanstvenim radovima usmjerenim na njihovo funkcioniranje, i dalje je aktivna rasprava o tome u kojoj mjeri treba poticati privatizaciju s obzirom na učinke koje ona ima na gospodarstvo. U sferi proučavanja efekata privatizacije na zaposlenost, ovaj rad se fokusira na zbivanja na tržištu rada u Hrvatskoj. Pri tome je primarni naglasak na analizi zaposlenosti po granama djelatnosti te prema obliku vlasništva. Glavni cilj rada je utvrđivanje utjecaja privatizacije, odnosno rastućeg udjela privatnog vlasništva, na zaposlenost u Hrvatskoj. Procjena se vrši OLS metodom u statističkom paketu EViews. Rezultati ekonometrijske analize upućuju na to da povećanje udjela privatnog vlasništva vodi do rasta zaposlenosti. S obzirom na dobivene rezultate preporuča se dodatno smanjivanje visokog udjela državnog vlasništva u Republici Hrvatskoj.

Ključne riječi: tranzicija, privatizacija, struktura vlasništva, zaposlenost

JEL klasifikacija: C13, G32,J21, L33

\section{Abstract}

In the public discourse of transition economies, as well as in scientific literature focused on their functioning, there is still an active debate on whether privatization should be encouraged in view of its effects on the economy. In the context of the effects of privatization on employment, this paper focuses on labor market developments in Croatia. The primary emphasis is on the analysis of employment by activity and ownership type. The main aim of the paper is to determine the impact of privatization, i.e. the growing share of private ownership, on employment in Croatia. The estimate is conducted using the OLS method in the EViews statistical package. The results of the econometric analysis indicate that the increase in the share of private property leads to an increase in employment. In view of the results obtained it is recommended to further reduce the high share of state ownership in the Republic of Croatia.

Keywords: transition, privatization, ownership structure, employment

JEL classification: $\mathrm{C} 13, \mathrm{G} 32, \mathrm{~J} 21, \mathrm{~L} 33$

\section{Uvod}

Hrvatska je,zajedno s ostalim komunističkim/socijalističkim zemljama,u drugoj polovici dvadesetog stoljeća započela proces ubrzanog razvoja temeljenog na razvoju industrije. Razdoblje prosperiteta trajalo je do osamdesetih godina prošlog stoljeća, a počet- kom devedesetih sve socijalističke zemlje, pa tako i Hrvatska, kreću u proces tranzicije sa socijalističkih na kapitalističke ekonomske sustave. Međutim, ulaskom u tranziciju, industrije ovih zemalja suočavaju se s brojnim problemima koje dovode do drastičnog pada industrije i zaposlenosti.

\section{Doc. dr.sc. Marija Beg}

Ekonomski fakultet Sveučilišta u Zagrebu E-mail:mbeg@efzg.hr

\section{Mergl Domenika, mag. oec.}

PricewaterhouseCoopers d.0.0. E-mail:mergl.domenika@gmail.com

\section{Asst. prof. Marija Beg, PhD}

Faculty of Economics and Business, University of Zagreb

E-mail: mbeg@efzg.hr

\section{Mergl Domenika, mag. oec.}

PricewaterhouseCoopers d.0.o.

E-mail:mergl.domenika@gmail.com 
Beg, M., Mergl, D.

Analiza utjecaja oblika vlasništva na zaposlenost u Hrvatskoj
Hrvatski tranzicijski proces bio je specifičan zbog nekoliko faktora, uključujući rat, ali ponajviše zbog društvenog vlasništva umjesto uobičajenog državnog vlasništva u preostalim planskim gospodarstvima. Taj specifični oblik vlasništva doveo je do veće zainteresiranosti djelatnika za sudbinu tvrtke u kojoj su bili zaposleni i rezultate njezina poslovanja. Međutim, proces privatizacije koji je omogućio prodaju dionica uz popust zaposlenima u visini od $50 \%$ procijenjene vrijednosti poduzeća rezultirao je pojavom mnoštva malih dioničara, bez prethodnog znanja o tome što bi trebali učiniti sa svojim dionicama i bez odgovarajuće pravne regulative i zaštite. Također, unatoč društvenom vlasništvu te značajnoj slobodi malih $\mathrm{i}$ srednjih poduzeća u odlučivanju o veličini, strukturi i raspodjeli dohotka na potrošnju i štednju, utjecaj države i političkih faktora bio je snažan u velikim poduzećima koja su dominirala ekonomskom strukturom (Družić i suradnici, 2003.).

Posljedično, Hrvatska se nerijetko navodi kao jedan od neuspješnih primjera tranzicije s planskog na tržišno gospodarstvo i to najvećim dijelom zbog privatizacije državnih poduzeća, koja je po mnogima uništila hrvatsku industriju (Družić, 1997b., Šundalić, 2012.). lako je privatizacija česta tema u javnom diskursu (zbog korupcije, neispunjenih ciljeva privatizacije i sl.), rijetko se raspravlja o tržištu rada koje se drastično promijenilo od vremena planskog gospodarstva do danas, dok empirijska istraživanja o navedenoj vezi ne postoje. Zaposlenih u industrijskim djelatnostima je svakim danom sve manje premda je osnovni ekonomski cilj privatizacije povećanje produktivnosti i motivacije za radnike i menadžere. Tako bi privatizacija trebala olakšati strukturne promjene u ekonomiji uz niži trošak zaposlenosti.

Cilj ovog rada je prikazati utjecaj privatizacije odnosno promjene strukture vlasništva (privatno vs. javno) na razinu zaposlenosti. Naime, budući da privatni sektor raste, trebao bi privlačiti sve više zaposlenih. U skladu s tim, veći udio privatnog vlasništva trebao bi implicirati veću zaposlenost, ceteris paribus.U tom kontekstu se najprije analizira proces privatizacije te se ekonometrijskom analizom testira utjecaj oblika vlasništva na zaposlenost.
Nakon uvodnog dijela slijedi pregled literature nakon čega se u trećem dijelu rada opisuje proces privatizacije te njezin utjecaj na strukturu BDP-a i vlasničku strukturu.U tom će kontekstu biti analizirana zaposlenost s obzirom na oblik vlasništva. Nakon toga, u četvrtom dijelu rada, uslijedit će regresijska analiza kojom će se pokušati dokazati utjecaj oblika vlasništva na zaposlenost.U petom dijelu se interpretiraju rezultati modela te na kraju slijedi zaključak.

\section{Pregled literature}

Glavni razlog za privatizaciju su postojanje asimetričnih informacija i nepotpunih ugovora koji vode do ozbiljnih problema s poticajima te posljedično, do gubitka učinkovitosti u javnim poduzećima (poznato u literaturi kao problem principala i agenta). Literatura pokazuje kako privatizacija ubrzava proces restrukturiranja, a to ima odlučujući značaj za uspjeh tranzicije, te posljedično i za porast zaposlenosti. Privatizirana poduzeća u tranzicijskim gospodarstvi$\mathrm{ma}^{1}$ pokazuju višu učinkovitost od javnih poduzeća (vidi npr.Pohl i suradnici,1997.ili Frydman i suradnici, 1997.) iako se pokazalo da je potrebno izvjesno vrijeme za prilagodbu i napuštanje modela ponašanja državnih poduzeća. Također postoji i određena pristranost u ocjeni privatizacije iz razloga što se uvijek prvo privatiziraju bolja poduzeća (Smith i suradnici, 1997., Veselica i Vojnić, 2000.). Na uspjeh privatizacije utječe i način na koji se privatizacija provodi. Gregurek (2001.) zaključuje kako Hrvatska do 2001. godine nije bila privlačna stranim investitorima upravo zbog niskog stupnja privatizacije. Naime, inozemna ulaganja tijekom 1990-ih godina, s izuzetkom Mađarske i Poljske, čine praktički beznačajan iznos u svim tranzicijskim gospodarstvima, pa tako i u hrvatskom.S druge pak strane, domaći izvori kapitala značajno su reducirani, jer su ratna zbivanja i tranzicijska recesija učinili od domaće štednje beznačajnu veličinu (Družić, 2004.).

Frydman i suradnici (1997.) empirijski pokazuju kako privatizirana poduzeća ostvaruju znatne probitke od zapošljavanja u odnosu na javna poduzeća. Budući da je njihova superiornija sposobnost stvaranja prihoda, a ne sposobnost smanjivanja troškova, ta koja

1 Istraživanja su uglavnom provedena za CEE zemlje (zemlje srednje i istočne Europe - Albanija, Bugarska, Češka, Hrvatska, Mađarska, Poljska, Rumunjska, Slovačka, Slovenija i Baltičke zemlje: Estonija, Latvija i Litva) dok je literatura koja se bavi ostalim tranzicijskim zemljama iznimno rijetka. 
tvrtki omogućuje održavanje postojeće ili povećanje zaposlenosti, privatizacija postaje dominantna strategija zapošljavanja u tranziciji. Frydman i suradnici (1999.) u svom kasnijem radu uspoređuju performanse privatiziranih i državnih poduzeća u tranzicijskim gospodarstvima srednje Europe te zaključuju kako privatizacija ima različite učinke ovisno o obliku vlasništva koje poprima. Konkretno, privatizacija koja nije išla prema zaposlenicima poduzeća pokazala je značajne pozitivne efekte na performanse poduzeća.

Slično pokazuju i Zinnes i suradnici (2001.). Analiziraju tendenciju izjednačavanja promjene vlasništva s privatizacijom te činjenicu da je sama promjena vlasništva imperativ politike. Identificiraju važnost dodatnih čimbenika kao što su tvrda proračunska ograničenja, tržišno natjecanje, depolitizacija ciljeva poduzeća, kao i razvoj institucija i regulatorni okvir koji će ih podržati te empirijski dokazuju na uzorku od 24 zemlje kako sama promjena vlasništva nije dovoljna za postizanje pozitivnih ekonomskih učinaka. Za potonje je potrebno postići neki prag vrijednosti navedenih čimbenika nakon čega se očituju pozitivni učinci privatizacije. Također, zaključuju kako su početni uvjeti igrali važnu ulogu.

Konačno, pregled literature ukazuje na probitke od privatizacije. Efekti se mogu razlikovati ovisno o početnoj poziciji, načinu privatizacije i slično, međutim pozitivni učinci su neosporni. Stoga ima smisla istražiti vezu između oblika vlasništva od početka tranzicije do danas i utjecaj privatizacije na tržište rada, konkretno na zaposlenost.

\section{Analiza strukture BDP-a i zaposlenosti prema oblicima vlasništva}

Stupanj privatiziranosti u Hrvatskoj i danas je podložan različitim tumačenjima. Naime, još uvijek se ne zna točan broj poduzeća koja su ušla u proces privatizacije. Razlog tome je činjenica da su objavljivani podatci bili podložni čestim promjenama metodologije, a zbog ratnih neprilika u promatranom razdoblju bilo je poprilično teško doći do bilo kakvih relevantnih podataka. Stoga se u radu analizira vlasnička struktura po pojedinim granama djelatnosti.

Prema Družiću (1997.a) problemi privatizacije u zemljama tranzicije uglavnom se svode na probleme privatizacije u industriji. Također, kretanje industrijske proizvodnje oslikava uspješnost tržišne tranzicije. Na Slici 1. prikazana je sektorska struktura BDP-a iz 1990. godine gdje je vidljiv dominantan udio industrije u BDP-u (tada definiran kao bruto društveni proizvod zbog prevladavajućeg društvenog vlasništva). Očito je da udio od 37\% u BDP-u industriju čini najznačajnijom djelatnosti u Hrvatskoj početkom tranzicijskog procesa. Nakon industrije, najveći udio u BDP-u imaju trgovina, a zatim poljoprivreda i ribarstvo te promet i veze.

Nakon analize djelatnosti po njihovom udjelu u BDP-u važno je sagledati vlasničku strukturu po pojedinim granama djelatnosti u Hrvatskoj.U Tablici 1. prikazana je vlasnička struktura BDP-a Hrvatske po granama djelatnosti u 1990. godini. Samim uvidom

Slika 1. Sektorska struktura BDP-a (društvenog proizvoda) Hrvatske 1990. godine

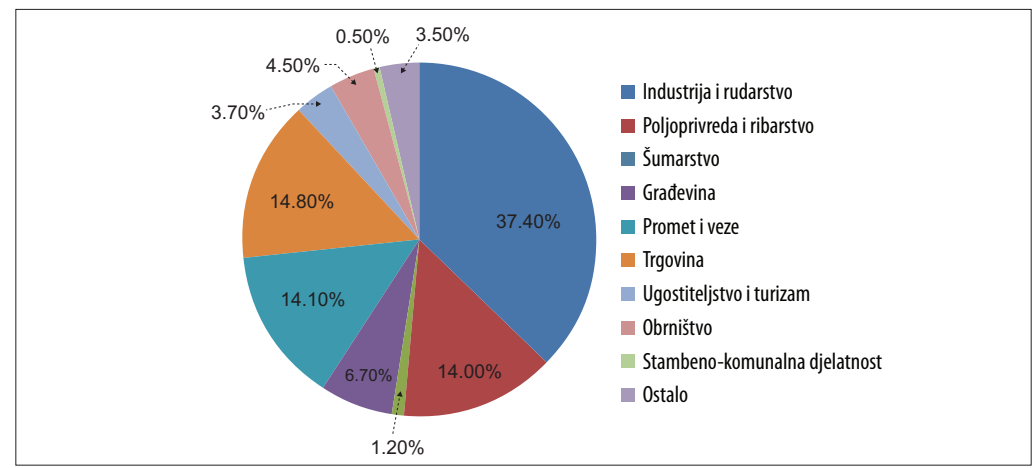

Izvor: DZS (1993.). 
Beg, M., Mergl, D.

Analiza utjecaja oblika vlasništva na zaposlenost u Hrvatskoj u Tablicu 1. može se potvrditi kako je u pojedinim granama djelatnosti prisutno privatno vlasništvo, čak i prije započetog procesa pretvorbe i privatizacije.

U poljoprivredi i trgovini privatni je sektor činio $50 \%$ ukupnog vlasništva te je slična situacija vidljiva i u djelatnosti obrtništva gdje je udio privatnog vlasništva početkom tranzicije bio oko 70\%. Međutim, u najznačajnijoj grani djelatnosti, industriji, dominiralo je društveno vlasništvo s udjelom od $80 \%$. Uzmemo li u obzir dva prethodno navedena podatka, da je u razmatranju sektorske strukture BDP-a industrija imala najveći udio te da je industrijom dominiralo društveno vlasništvo, nije teško zaključiti zašto je oporavak industrijske proizvodnje uvijek centralno pitanje svih post tranzicijskih zemalja. Najveći udio društvenog vlasništva bio je u djelatnostima šumarstva, vodoprivrede i zdravstvene zaštitite i socijalne skrbi (100\%). Društveno vlasništvo je također dominiralo (od 70\% - 95\%) u djelatnostima ugostiteljstva i turizma, prometa i veza, stambeno-komunalnih djelatnosti te obrazovanja i kulture.

Analiza vlasničke strukture važna je zbog analize kretanja zaposlenosti po granama djelatnosti prema obliku vlasništva. Obzirom da je tema rada utjecaj oblika vlasništva na razinu zaposlenosti u Hrvatskoj, od ključne je važnosti razdvajanje grana djelatnosti na one koje su u pretežito privatnom i pretežito državnom vlasništvu za potrebe ekonometrijske analize. Kako bi razumjeli vlasničku strukturu poduzeća nakon završenog procesa privatizacije bitno je razumjeti što stoji u pozadini pojedinih grana djelatnosti te kako se vlasnička struktura razvijala po djelatnostima od 1990. do danas.

Na Slici 2. prikazana je struktura BDP-a po djelatnostima za vrijeme privatizacijskog procesa (1996. godine), a na Slici 3. prikazani su najnoviji dostupni podatci za strukturu BDP-a po djelatnostima (2015. godine). Treba napomenuti da se metodologija sakupljanja i obrade podataka bitno promijenila od 1990. godine do danas, no promjene se uglavnom odnose na detaljniju razradu pojedinih skupina djelatnosti, pretežito onih iz tercijarnog sektora zbog sve većeg udjela u BDP-u. Za potrebe ove analize djelatnosti sa sličnim karakteristikama grupirane su u skupine radi bolje usporedivosti s onima iz 1990. godine, a po NKD-u 2007.

Na Slikama 2. i 3. vidljiva je promjena sektorske strukture BDP-a gdje se posebno ističe znatno smanjenje udjela industrije u BDP-u. S visokih predtranzicijskih 37\%, sektor industrije (područja B, C, D i E) 1996. godine iznosi samo 24\% BDP-a, a 2015. godine 21\% BDP-a, odnosno dogodila se deindustrijalizacija. Sektor poljoprivrede (područje A) također je doživio veliko relativno smanjenje u godinama nakon početka tranzicije (s 15,2\% BDP-a u pred tranzicijskom razdoblju na 7\% BDP-a u 1996. godini, a u 2015. godini iznosi 4\% BDP-a). U preostalim sektorima dogodile su se određene promjene, no ne toliko značajne. Primjerice, sektor građevine (područje F) od 1990. do 1996. godine nije se promijenio te čini 7\% BDP-a, međutim, 2015. godine njegov se udio smanjuje za 2 postotna poena na ukupno 5\% BDP-a. Sektori trgovine, ugostiteljstva i turizma te prometa i veza prije tranzicije iznose

Tablica 1. Vlasnička struktura BDP-a (društvenog proizvoda) Hrvatske 1990. godine

\begin{tabular}{|c|c|c|c|c|}
\hline & & \multicolumn{2}{|c|}{ Sektori (izraženo u \%) } \\
\hline & Društveni & Privatni & Zadružni & Mješoviti \\
\hline Industrija i rudarstvo & 87,20 & 7,80 & - & 5,00 \\
\hline Poljoprivreda i ribarstvo & 37,90 & 52,50 & 4,10 & - \\
\hline Sumarstvo & 99,60 & 0,40 & - & - \\
\hline Vodoprivreda & 100,00 & - & - & 21,80 \\
\hline Građevinarstvo & 47,00 & 27,80 & 3,40 & 3,00 \\
\hline Promet i veze & 88,90 & 7,70 & 0,40 & 5,60 \\
\hline Trgovina & 49,00 & 43,90 & 1,50 & 4,60 \\
\hline Ugostiteljstvo i turizam & 71,00 & 24,30 & 0,10 & 1,60 \\
\hline Obrtništvo & 24,40 & 69,20 & 4,80 & 0,80 \\
\hline Stambeno-komunalne djelatnosti & 94,50 & 4,70 & - & 6,30 \\
\hline Financijske i druge usluge & 52,10 & 41,30 & 0,30 & 13,60 \\
\hline Obrazovanje i kultura & 86,40 & - & - \\
\hline Zdravstvena zaštita i socijalna skrb & 100,00 & - & - \\
\hline
\end{tabular}

Izvor: Družić (1997. a) prema DZS (1993.). 
ukupno 32,6\% od ukupnog BDP-a. Ako navedeno usporedimo s granama djelatnosti G, H, I (trgovina na veliko i malo, prijevoz i skladištenje te usluge pružanja smještaja i pripreme hrane) ispada da se udio za promatrane grane djelatnosti s godinama smanjio na 22\% BDP-a. Međutim, navedenu informaciju ne možemo uzeti kao relevantnu jer su po NKD-u 2007. uslužne djelatnosti puno detaljnije razrađene po granama (razredima) nego po JKD-u (Jedinstvenoj klasifikaciji djelatnosti) pa je i logično da se udio smanjio obzirom da se dio klasificirao u druge grane djelatnosti.

Na Slici 4. prikazano je kretanje aktivnih pravnih osoba prema obliku vlasništva kroz razdoblje od
2001. do 2016. godine. Državni zavod za statistiku (DZS) objavljuje navedene podatke na tromjesečnoj bazi od 1999. godine. Međutim, oni nisu sasvim usporedivi. Nedostatak ove vremenske serije je taj što DZS od 2002. godine za određeni broj pravnih 0soba prestaje pratiti oblik vlasništva. Iz tog je razloga od 2002. godine na Slici 4 vidljiv određeni udio poduzeća za koji se vlasništvo ne prati i označen je kao „nema vlasništva“. Udio takvih pravnih osoba se kreće od $11 \%$ u 2002. godini do 20\% u 2016. godini. Međutim,zanimljivo je da udio registriranih pravnih osoba u državnom vlasništvu koji je iznosio visokih $14 \%$ u 2001. godini već sljedeće godine iznosi samo $1,3 \%$, a od 2007. godine pada ispod $1 \%$. Mala je vjerojatnost da je $13 \%$ registriranih poduzeća u samo

Slika 2. Sektorska struktura BDP-a Hrvatske 1996. godine prema NKD 2007.

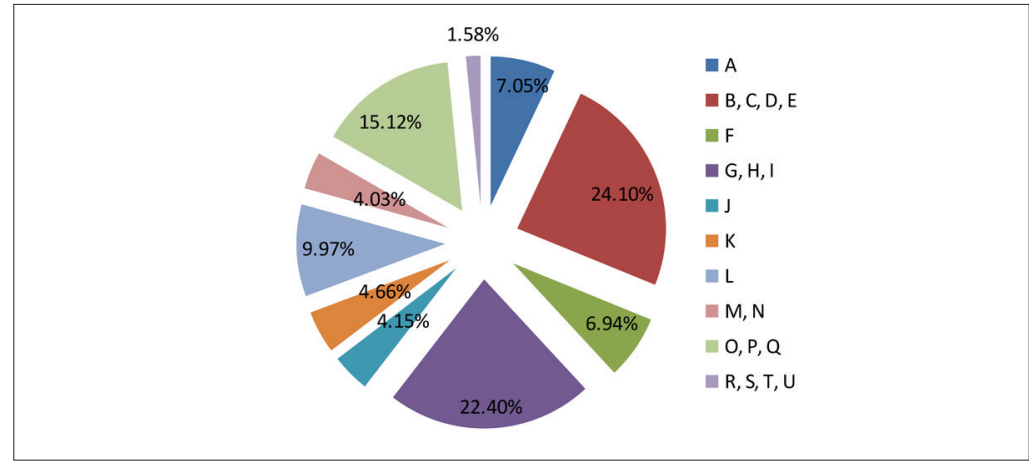

Izvor: DZS (2009.).

Slika 3. Sektorska struktura BDP-a Hrvatske 2015. godine prema NKD 2007.

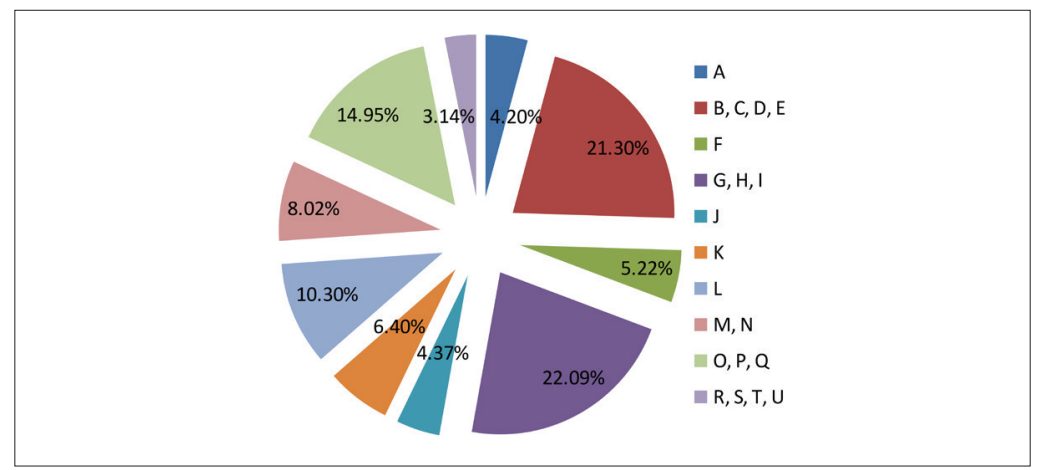

Izvor: DZS (2017.b). 
Beg, M., Mergl, D.

Analiza utjecaja oblika vlasništva na zaposlenost u Hrvatskoj

Slika 4. Struktura aktivnih pravnih osoba prema oblicima vlasništva (2001. - 2016.)

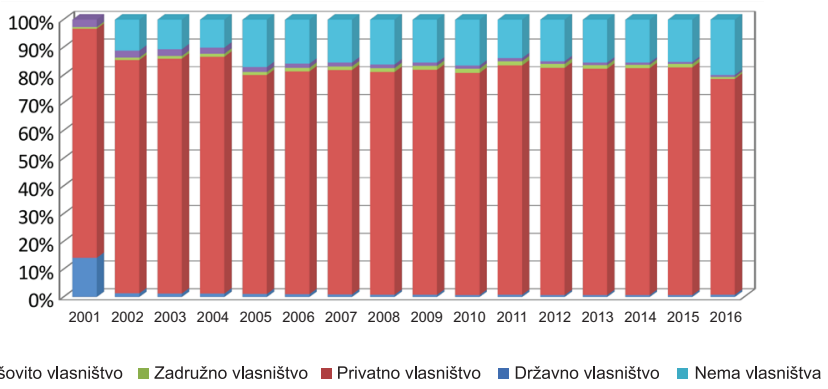

Izvor: DZS (2017.a).

godinu dana prešlo iz kategorije državnog u privatno vlasništvo, dok je kategorija „nema vlasništva“ najednom visoka, pa se u radu pretpostavlja da se promjenom metodologije za većinu registriranih pravnih osoba u državnom vlasništvu od 2002. godine prestalo pratiti vlasništvo, to jest, svrstani su u kategoriju „nema vlasništva“.

Nakon prikazane strukture vlasništva po godinama detaljnije ćemo analizirati broj pravnih osoba prema djelatnostima NKD-a za 2001. (prije promjene metodologije) te 2016. godinu. Na Slici 5. vidljivo je da pravne osobe u državnom vlasništvu dominiraju razredima $\mathrm{E}$ - opskrba električnom energijom,javna uprava i obrana, M - obrazovanje, $\mathrm{N}$ - zdravstvena zaštita i socijalna skrb, 0 - ostale društvene, soci- jalne i osobne uslužne djelatnosti te $\mathbf{Q}$ - izvan teritorijalne organizacije što uključuje međunarodne organizacije te djelatnosti stranih diplomatskih i konzularnih predstavništva.

Na Slici 6. prikazana je ista struktura u 2016. Kao što je već navedeno, od 2002. godine primjenjivana je nova metodologija sakupljanja podataka pa se pojavljuje kategorija „nema vlasništva“. Osim navedenog, razlika je i u klasifikaciji djelatnosti. Naime, od 2009. godine podatci se sakupljaju i prikazuju prema NKD-u 2007. godine. Ako uzmemo u obzir navedeno, u 2016. godini nema značajnijih promjena. Razred E - opskrba električnom energijom, plinom i vodom po novom se NKD-u razdijelio na dva razreda D i E. Državno vlasništvo i dalje zauzima ve-

Slika 5. Struktura aktivnih pravnih osoba prema obliku vlasništva i područjima NKD-a 2002. u rujnu 2001. godine

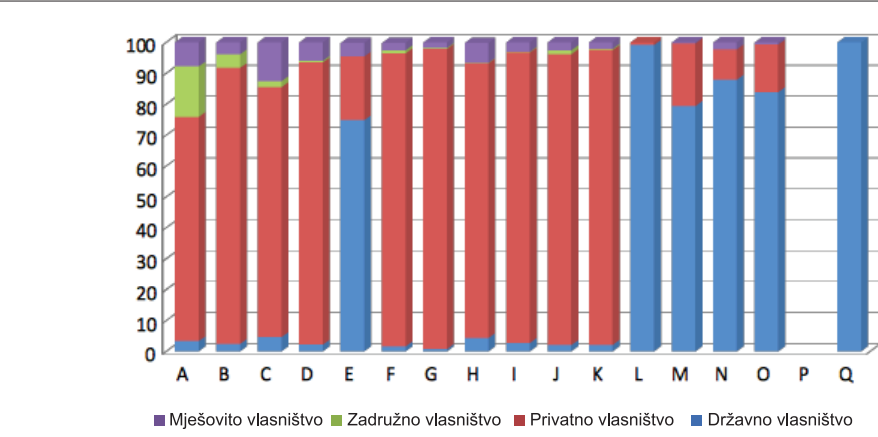

Izvor: DZS (2001.). 
Izvor: DZS (2016.a).

liki udio u razredu E - opskrba vodom. U preostalim razredima, u kojima je dominiralo državno vlasništvo 2001. godine, sada prevladava udio pravnih osoba za koje se vlasništvo ne prati. Kao i ranije, pretpostavit će se da se promjenom metodologije za dio pravnih osoba koje su 2001. godine kategorizirane kao državno vlasništvo od 2002. godine prestalo pratiti vlasništvo. Obzirom na navedeno, može se reći da područjima NKD-a 0 - javna uprava i obrana, $P$ - obrazovanje, $\mathbf{Q}$ - djelatnosti zdravstvene zaštite i $R$ - umjetnost, zabava i rekreacija dominira državno vlasništvo. Područje $S$ - ostale uslužne djelatnosti ne može se svrstati u pretežito državno vlasništvo iako se za čak $80 \%$ poduzeća u tom području oblik vlasništva ne prati. Naime, razred S podrazumijeva djelatnosti članskih organizacija (djelatnosti sindikata, djelatnosti vjerskih organizacija, djelatnosti političkih organizacija), popravak računala i predmeta za osobnu uporabu i kućanstvo te ostale uslužne djelatnosti (kemijsko čišćenje tekstila, frizerski saloni, pogrebne djelatnosti, djelatnosti za njegu i održavanje tijela itd.) (MINGO, 2017.). Po opisu ovog razreda NKD-a zaključuje se da ne pripada pretežito državnom sektoru. Nakon pregleda kretanja broja registriranih pravnih osoba prema obliku vlasništva, analizira se broj zaposlenih prema područjima NKD-a i obliku vlasništva. Pri ovoj analizi također se nailazi na problem usporedivosti podataka zbog promje-

Slika 7.Zaposlenost prema obliku vlasništva od 2005. do 2015. godine

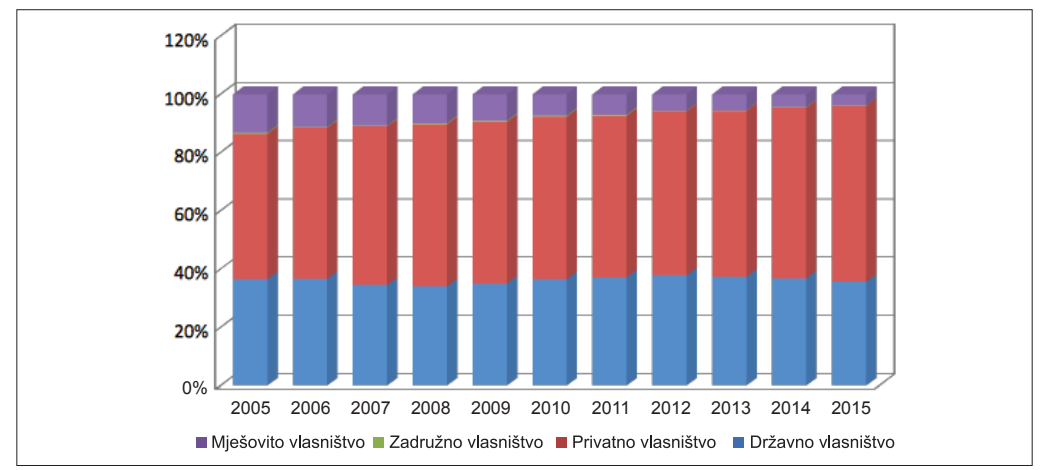

Izvor: DZS (2016.b). 
Beg, M., Mergl, D.

Analiza utjecaja oblika vlasništva na zaposlenost u Hrvatsko

Slika 8. Struktura zaposlenosti po područjima NKD-a i obliku vlasništva u 2005. godini

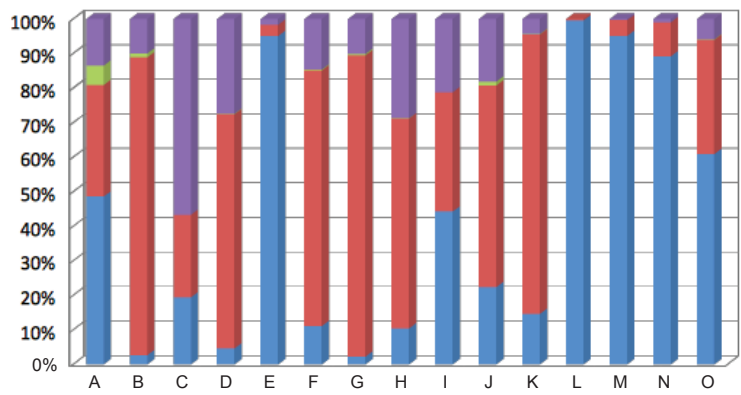

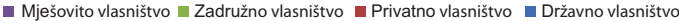

Izvor: DZS (2016.b).

na u klasifikaciji djelatnosti. Na Slici 7. vidljivo je smanjenje udjela broja zaposlenih u državnom sektoru u usporedbi sa strukturom zaposlenosti iz 1996. godine kada je, prema podatcima Statističkog ljetopisa Hrvatske iz 1997. godine, čak 49\% radnika bilo zaposleno u državnom sektoru (DZS, 1997.). Znatno smanjenje udjela zaposlenih u državnom sektoru je rezultat privatizacije brojnih poduzeća i nakon 1996. godine. Danas se udio zaposlenih u državnom sektoru kreće uglavnom u rasponu od $34-37 \%$, dok se udio zaposlenih u privatnim poduzećima povećava s $50 \%$ u 2005. godini na $60 \%$ u 2015. godini. Osim privatnog i državnog, na Slici 7. je vidljiv i određeni udio zadružnog te mješovitog vlasništva. Međutim, udio zadružnog vlasništva je kroz promatrano razdoblje manji od $1 \%$, a udio mješovitog vlasništva se svake godine sve više smanjuje te 2015 . godine doseže $4 \%$ Obzirom na tako nizak udio u ukupnoj zaposlenosti, zadružno i mješovito vlasništvo će se apstrahirat iz ove analize, a naglasak analize bit će na kretanju zaposlenosti u privatnom i državnom vlasništvu.

Kada se promotri struktura zaposlenosti prema obliku vlasništva po pojedinim granama NKD-a (Slike 8. i 9.), vidljivo je da u pojedinim granama djelatnosti prevladava državno vlasništvo. Ako se usporede djelatnosti kojima dominira državno vlasništvo 2005. i 2015. godine s istima prije tranzicije vidljiv je određeni trend. Primjerice,

Slika 9. Struktura zaposlenosti po područjima NKD-a i obliku vlasništva u 2015. godini

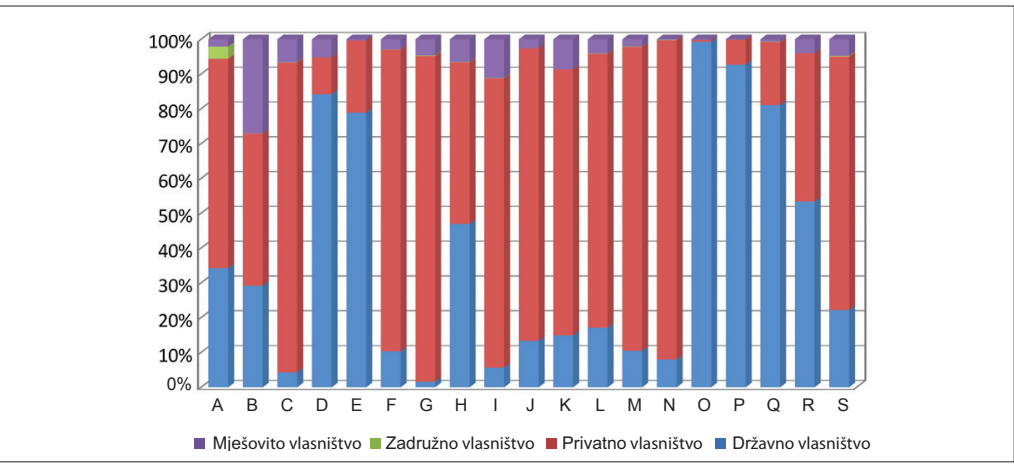

Izvor: DZS (2016.b). 
djelatnosti javne uprave i obrane, obrazovanja i zdravstvene i socijalne skrbi su u pretežito državnom vlasništvu još od predtranzicijskog razdoblja. Navedeno je i logično obzirom da se radi o uslugama od javnog interesa koje se financiraju iz proračuna.

Osim navedenih grana, djelatnost kojom također dominira državno vlasništvo je razred $\mathrm{E}$ - opskrba električnom energijom, plinom i vodom (NKD 2002) u 2015. godinom, to jest, prema NKD-u 2007. razred D - opskrba električnom energijom i E - opskrba vodom. Navedena grana djelatnosti je bila u pretežito državnom vlasništvu i prije procesa privatizacije pa nije teško za zaključiti kako u ovom sektoru privatizacija nije provedena, a prvenstveno zbog velikih energetskih kompanija koje su od državnog interesa.

Na Slici 9. može se vidjeti kako je i danas, 25 godina nakon započetog procesa privatizacije, još uvijek veliki udio zaposlenih u državnom sektoru te gotovo nema grane djelatnosti u kojoj ne postoji određeni broj zaposlenih u državnim poduzećima. Naime, postavlja se pitanje isplativosti tako velikog državnog aparata te mogućnosti daljnje privatizacije državnih poduzeća.

\section{Empirijska analiza utjecaja oblika vlasništva na zaposlenost}

\subsection{Definicija javnog i privatnog sektora u modelu}

Za podjelu grana djelatnosti na privatno i državno vlasništvo koristila se Nacionalna klasifikacija djelatnosti (NKD 2007.). U prethodnom dijelu rada prikazana je zaposlenost po navedenim djelatnostima prema obliku vlasništva. No, obzirom da se podatci o zaposlenosti prema obliku vlasništva ne prikupljaju na kvartalnoj razini, bilo je potrebno definirati grane djelatnosti koje se smatraju u pretežito državnom vlasništvu, i obrnuto, kako bi se došlo do relevantnih podataka za ekonometrijsku analizu. Obzirom da je u granama djelatnosti 0 - javna uprava i obrana, $P$ - obrazovanje i $Q$ zdravstvena zaštita 2015. godine (vidjeti Sliku 9.) dominiralo državno vlasništvo (više od $80 \%$ ), za potrebe ove regresijske analize navedene grane djelatnosti klasificirane su kao državni sektor, a sve ostale su klasificirane kao privatni sektor.

\subsection{Opis metodologije i izvor podataka}

Glavni izvor podataka je baza podataka Državnog zavoda za statistiku Republike Hrvatske. Podatci su preuzeti iz baza podataka ili objavljenih statističkih izvješća i priopćenja Državnog zavoda za statistiku (DZS, 2017.a, 2017.c, 2017.d). Kako su neki od prikupljenih podataka objavljivani na mjesečnoj razini tako su za potrebe ove analize računati prosjeci mjesečnih podataka i na taj način uprosječeni su podaci za pojedine kvartale kako bi se došlo do usporednih kvartalnih podataka. Analiza se provodi za razdoblje od drugog kvartala 2007. godine do četvrtog kvartala 2016. godine. Procjena se vrši uz softversku podršku programa EViews 7.

Kako bi se ispitao utjecaj oblika vlasništva na razinu zaposlenosti u Hrvatskoj primjenom metode najmanjih kvadrata procjenjuje se sljedeći model višestruke linearne regresije:

$\left(\right.$ STZAP $\left._{t}\right)=\alpha+\beta_{1}$ PRIVATNI $_{t}+\beta_{2}$ UDIOPRIV $_{t}+\beta_{3} S R \_B D P_{t}+\varepsilon$

pri čemu zavisna varijabla STZAP označava stopu zaposlenosti u Hrvatskoj, dok su nezavisne varijable PRIVATNI - stope rasta bruto dodane vrijednosti po djelatnostima koje smo prethodno klasificirali kao djelatnosti kojima dominira privatno vlasništvo (postotna promjena u odnosu na prethodno razdoblje), UDIOPRIV - udio broja privatnih poduzeća u ukupnom broju registriranih pravnih osoba,SR_BDP - stope rasta BDP-a (postotna promjena u odnosu na isto razdoblje u prethodnoj godini). Opis korištenih varijabli nalazi se u Tablici 2 .

Stopa zaposlenosti određena je kao zavisna varijabla jer je cilj rada prikazati utjecaj oblika vlasništva na razinu zaposlenosti. Zbog navedenog, kao nezavisne varijable odabrane su stope rasta bruto dodane vrijednosti po djelatnostima u kojima dominira privatno vlasništvo. Navedene djelatnosti su detaljno analizirane i objašnjene u prethodnom poglavlju, a odnose se na sve djelatnosti izuzev grana djelatnosti 0 - javna uprava i obrana, $P$ - obrazovanje i Q - zdravstvena zaštita.

Osim bruto dodane vrijednosti po djelatnostima kao nezavisne varijable korištene su i realne stope rasta BDP-a koje su definirane kao postotne promjene vrijednosti BDP-a u odnosu na isti kvartal prethodne godine. U ekonometrijsku analizu uključena je i nezavisna varijabla UDIOPRIV koja se definira
Beg, M., Mergl, D.

Analiza utjecaja oblika vlasništva na zaposlenost u Hrvatskoj 
Beg, M., Mergl, D.

Analiza utjecaja oblika vlasništva na zaposlenost u Hrvatsko

Tablica 2. Opis korištenih varijabli

\begin{tabular}{|c|c|c|c|}
\hline Oznaka varijable & Opis varijable & Izvor & $\begin{array}{l}\text { Očekivani teorijski } \\
\text { predznak }\end{array}$ \\
\hline STZAP & $\begin{array}{l}\text { Kvartalne stope zaposlenosti u Hrvatskoj (stopa } \\
\text { zaposlenosti je jednaka omjeru broja zaposlenih i radne } \\
\text { snage }\end{array}$ & DZS & ${ }^{2}$ \\
\hline PRIVATNI & $\begin{array}{l}\text { Stope rasta bruto dodane vrijednosti po djelatnostima } \\
\text { koje smo prethodno klasificirali kao djelatnosti kojima } \\
\text { dominira privatno vlasništvo }\end{array}$ & DZS, izračun autora & Pozitivan \\
\hline UDIOPRIV & $\begin{array}{l}\text { Udio broja privatnih poduzeća u ukupnom broju } \\
\text { registriranih pravnih osoba u RH }\end{array}$ & DZS & Pozitivan \\
\hline SR_BDP & $\begin{array}{l}\text { Realne stope rasta - odnos prema istom tromjesečju } \\
\text { prethodne godine }\end{array}$ & DZS & Pozitivan \\
\hline
\end{tabular}

Izvor: izrada autora.

Tablica 3. Osnovni statistički pokazatelji varijabli

\begin{tabular}{|c|c|c|c|c|}
\hline & DSR BDP & DSTZAP & DUDIOPRIV & PRIVATNI \\
\hline Mean & $-0,085296$ & 0,04103 & $-0,08974$ & 0,00739 \\
\hline Median & 0,062669 & $-0,30000$ & $-0,10000$ & 0,03268 \\
\hline Maximum & 2,979902 & 5,60000 & 3,50000 & 0,12451 \\
\hline Minimum & $-7,217887$ & $-3,10000$ & $-4,40000$ & $-0,10820$ \\
\hline Std.Dev. & 1,540722 & 1,55305 & 0,96376 & 0,09213 \\
\hline Skewness & $-2,321485$ & 1,00411 & $-0,86313$ & $-0,04281$ \\
\hline Kurtosis & 1,322292 & 5,45431 & 16,26033 & 1,14569 \\
\hline Jarque-Bera & 204,8561 & 1,63420 & 290,57630 & 5,59941 \\
\hline Probability & 0,000000 & 0,00028 & 0,00000 & 0,06083 \\
\hline & & & & \\
\hline Sum & $-3,32656$ & 1,60000 & $-3,50000$ & 0,28831 \\
\hline Sum Sq. Dev. & 90,20529 & 91,65436 & 35,29590 & 0,32256 \\
\hline Observations & 39 & 39 & 39 & 39 \\
\hline
\end{tabular}

Izvor: izrada autora.

kao udio broja privatnih poduzeća u ukupnom broju registriranih pravnih osoba u Hrvatskoj. Očekivani predznak za ovu varijablu je pozitivan iako su Bastos i suradnici (2014.) ekonometrijskom analizom na primjeru Portugala prikazali da privatna poduzeća prilikom maksimiziranja profita pokušavaju raditi na manjoj razini zaposlenosti. Pretpostavka je da u Hrvatskoj privatno vlasništvo povećava ukupnu zaposlenost zbog veće produktivnosti, više razine ulaganja u dodatno obrazovanje svojih zaposlenika, što posljedično povećava profit te potrebu za zapošljavanjem dodatnih radnika.

Deskriptivna statistika svih korištenih varijabli prikazana je u Tablici 3.

Nad podatcima su izvršene potrebne statističke provjere stacionarnosti nizova (provjera ADF testom na temelju čijih se rezultata zaključuje da su svi promatrani nizovi integrirani reda I, to jest I(1), pa se $u$ analizu ulazi s njihovim diferenciranim vri- jednostima, osim varijable PRIVATNI koja je stacionarna u razinama.

Rezultati provedene analize prikazani su u Tablici 4. Nakon procijenjene regresijske jednadžbe važno je provesti dijagnostiku modela koja uključuje testove multikolinearnosti, autokorelacije, heteroskedastičnosti i normalnosti grešaka relacije. Na temelju dobivenih rezultata standardnih testova zaključuje se da u modelu nije prisutan problem multikolinearnosti; uz razinu signifikantnosti od $1 \%(\alpha=0,01)$ ili $5 \%(\alpha=0,05)$ ne može se odbaciti hipoteza HO o nepostojanju autokorelacije grešaka relacije za sve pomake $k, k \leqslant 16$; prema Breusch-Pagan-Godfreyevom testu se zaključuje da u modelu nema problema heteroskedastičnosti.

Posljednji test se odnosi na ispitivanje normalnosti grešaka relacije. Pretpostavku o normalnosti grešaka relacije ispitujemo pomoću Jarque-Beraovog 
Tablica 4. Rezultati višestruke linearne regresijske analize za Hrvatsku (od 2007.02 - 2016. Q4)

\begin{tabular}{|c|c|c|c|c|}
\hline Dependent Variable: DSTZAP & & & & \\
\hline Method: Least Squares & & & & \\
\hline Sample: 200702201604 & & & & \\
\hline Included observations: 39 & & & & \\
\hline Variable & Coefficient & Std. Error & t-Statistic & Prob. \\
\hline $\mathrm{C}$ & $-0,026479$ & 0,214686 & $-0,123340$ & 0,90250 \\
\hline DUDIOPRIV & 0,061493 & 0,228311 & 0,269337 & 0,78930 \\
\hline DSR BDP & $-0,017687$ & 0,143239 & $-0,123480$ & 0,90240 \\
\hline PRIVATNI & 9,674019 & 2,343142 & 4,128653 & 0,00020 \\
\hline R-squared & 0,328437 & \multicolumn{2}{|c|}{ Mean dependent var } & 0,041026 \\
\hline Adjusted R-squared & 0,270874 & \multicolumn{2}{|c|}{ S.D. dependent var } & 1,553048 \\
\hline S.E. of regression & 1,326130 & \multicolumn{2}{|c|}{ Akaike info criterion } & 3,499321 \\
\hline Sum squared resid & 61,55171 & \multicolumn{2}{|c|}{ Schwarz criterion } & 3,669943 \\
\hline Log likelihood & $-64,23677$ & \multicolumn{2}{|c|}{ Hannan-Quinn criter. } & 3,560539 \\
\hline F-statistic & 5,705731 & \multicolumn{2}{|c|}{ Durbin-Watson stat } & 1,920405 \\
\hline Prob(F-statistic) & 0,002739 & & & \\
\hline
\end{tabular}

Izvor: izrada autora.

testa. Hipoteza H0 da su greške relacije normalno distribuirane odbacuje se kao lažna. Međutim,za razliku od dosadašnjih testova normalna distribuiranost grešaka relacije nije nužna za nepristranu procjenu parametara, već je upitna pouzdanost t-testa, F-testa i $X^{2}$ testa. Također, kako je Jarque-Bera asimptotski test, nije pogodan za male uzorke kao u ovom primjeru pa se rezultati testa ne mogu uzeti kao relevantni.

Nakon provedenih dijagnostičkih testova može se zaključiti da je model dobro definiran.

\section{Rezultati istraživanja}

Rezultati ocjene regresijske jednadžbe procijenjenih OLS metodom nalaze se u Tablici 4. U procijenjenom modelu samo jedna varijabla je značajna - varijabla PRIVATNI. Za nezavisnu varijablu UDIOPRIV dobiven je očekivani predznak, ali je p-vrijednost pripadajućeg koeficijenta pokazala kako varijabla nije značajna u modelu.Za nezavisnu varijablu SR BDP dobiven je suprotan predznak od očekivanog, no p-vrijednost je također pokazala kako niti ova varijabla nije značajna u modelu.

Navedeni model se pokušao proširiti dodatnim varijablama kako bi se testirala robustnost ovog rezultata. Varijable koje su se dodale u model bile su između ostalog stopa (ne)zaposlenosti, stopa rasta broja zaposlenih, stopa rasta radne snage, stopa rasta BDV-a u državnom sektoru, udio zaposlenih u državnom sektoru, broj zaposlenih u privatnom sektoru, broj poduzeća u privatnom vlasništvu te dummy varijabla za krizu iz 2008., no navedene var- ijable ili nisu bile značajne ili model nije bio dobro specificiran s obzirom na zahtijevanu dijagnostiku modela. Varijabla PRIVATNI se pak pokazala kao robustna u većini modela.

Navedeni rezultat interpretiramo na sljedeći način. Obzirom da je varijabla PRIVATNI definirana kao stopa rasta bruto dodane vrijednosti ostvarene u djelatnostima koje su prethodno definirane kao pretežito privatno vlasništvo, dobiveni rezultat pokazuje da ukoliko se nezavisna varijabla PRIVATNI poveća za $1 \%$, stopa zaposlenosti (udio zaposlenih u radnoj snazi) će se u prosjeku povećati za $9,7 \%$. Odnosno, ako se stopa rasta bruto dodane vrijednosti u privatnom sektoru poveća za $1 \%$, stopa zaposlenosti će se u prosjeku povećati za 9,7\%. Navedeni koeficijent je velik što ukazuje na veliki značaj privatnog sektora.

Rezultati modela bi vjerojatno bili kvalitetniji kada bi postajali usporedivi podatci za duži vremenski interval. S druge pak strane, ako se u obzir uzme specifičnost Hrvatske koja ima iznimno veliki udio države u svim segmentima ekonomskog „života“ jasno je da je ovakva analiza možda preuranjena te je teško dobiti signifikantne rezultate. U slučaju smanjivanja velikog javnog sektora navedena analiza bi se trebala provesti ponovno kako bi se mogli iščitati očekivani teoretski efekti. Rezultati jasno ukazuju na prednost smanjivanja visokog udjela države i pozitivne efekte privatnog vlasništva.

\section{Zaključak}

Privatizacija je općenito smatrana pozitivnom po-
Beg, M., Mergl, D.

Analiza utjecaja oblika vlasništva na zaposlenost u Hrvatskoj 
Beg, M., Mergl, D.

Analiza utjecaja oblika vlasništva na zaposlenost u Hrvatskoj javom te su se ekonomski efekti iste pokazali empirijski pozitivnima.Ipak, uz privatizaciju u Hrvatskoj vežu se uglavnom negativne značajke. Ciljevi privatizacije (definirani Zakonom o privatizaciji iz 1996.) ni približno nisu ostvareni. Skromni ekonomski rast i industrijska proizvodnja uslijedili su tek nekoliko godina nakon započetog privatizacijskog procesa. Međutim, radilo se o skoro neznatnom napretku koji nije bio popraćen stvaranjem novih radnih mjesta kako je inicijalno bilo zamišljeno. Restrukturiranje hrvatskog gospodarstva potrajalo je znatno duže od očekivanog što je imalo utjecaj i na tržište rada. Ovaj rad je stoga imao za cilj ut- vrditi kako je privatizacija, odnosno rast privatnog vlasništva utjecao na zaposlenost u Hrvatskoj. Kako se do sada u Hrvatskoj sličan model nije pokušao procijeniti, istraživanje je relevantno i atraktivno. Rezultati ekonometrijskog modela pokazali su da povećanje bruto dodane vrijednosti privatnog sektora rezultira većom stopom zaposlenosti. Navedeno implicira da bi stimuliranje rasta privatnog sektora (dodatnom privatizacijom državnih, često neefikasnih poduzeća te poticanjem privatnog poduzetništva) pridonijelo otvaranju novih radnih mjesta, a samim time i povećalo zaposlenost.

\section{Literatura}

Bastos, P., Monteiro, N.P., Straume, O. R. (2014) The Impact of Private vs. Public Ownership on the Level and Structure of Employment. Economics of Transition, 22 (2): 247-280.

Družić, I. (1997a) Razvoj i tranzicija hrvatskoga gospodarstva. Zagreb: Hrvatska akademija znanosti i umjetnosti i Politička kultura.

Družić, I. (1997b) Tržišno restrukturiranje i privatizacija hrvatskog gospodarstva. U: Hrvatsko gospodarstvo, I. Družić, (ur.) Zagreb: Ekonomski fakultet i Politička kultura: 109-134.

Družić, I. i dr. (2003) Hrvatski gospodarski razvoj.Zagreb: Ekonomski fakultet Zagreb \& Politička kultura.

Družić, I. (2004) Resursi i tržišta hrvatskog gospodarstva.Zagreb: Politička kultura.

DZS (1993) Statistički ljetopis Hrvatske, 1993.Zagreb: Državni zavod za statistiku.

DZS (1997) Statistički ljetopis Hrvatske, 1997.Zagreb: Državni zavod za statistiku.

DZS (2001) Priopćenje „Broj i struktura poslovnih subjekata u rujnu 2001.,,Zagreb. Dostupno na: https:// www.dzs.hr/ [15.9.2017].

DZS (2009) Priopćenje „Godišnji bruto domaći proizvod od 1995. do 2005.,, broj 12.1.3.,Zagreb, 28. siječnja 2009. Dostupno na: https://www.dzs.hr/Hrv/Publication/2009/12-1-3_1h2009.htm [15.9.2017].

DZS (2016a) Priopćenje „Broj i struktura poslovnih subjekata u rujnu 2016., broj 11.1.1/3., Zagreb, 9. studenoga 2016. Dostupno na: https://www.dzs.hr/ [15.9.2017].

DZS (2016b) Statistički ljetopis Hrvatske, razna godišta. Državni zavod za statistiku,Zagreb.

DZS (2017a) Priopćenja „Broj i struktura poslovnih subjekata“, razna godišta. Državni zavod za statistiku. Dostupno na: https://www.dzs.hr/ [15.9.2017].

DZS (2017b) Priopćenje „Godišnji bruto domaći proizvod za 2015., broj 12.1.4., Zagreb, 24. svibnja 2017. Dostupno na: https://www.dzs.hr/Hrv_Eng/publication/2017/12-01-04_01_2017.htm [15.9.2017].

DZS (2017c) Statistika u nizu. Bruto domaći proizvod. Državni zavod za statistiku. Dostupno na: https:// 
www.dzs.hr/ [15.9.2017].

DZS (2017d) Statistika u nizu. Aktivno stanovništvo. Državni zavod za statistiku. Dostupno na: https:// www.dzs.hr/ [15.9.2017].

Frydman, R., Gray, C., Rapaczynski,A.(1997) Private Ownership and Corporate Performance: Some Lessons from Transition Economies. The Policy Research Working Paper 1830, Development Research Group, The World Bank.

Frydman, R., Gray, C., Hessel, M., Rapaczynski, A. (1999) When Does Privatization Work? The Impact of Private Ownership on Corporate Performance in the Transition Economies. The Quarterly Journal of Economics, 114 (4): 1153-1191.

Gregurek, M. (2001) Stupanj i učinci privatizacije u Hrvatskoj. Ekonomski pregled, 52 (1-2): 155 -188.

MINGO (2017) NKD 2007. s objašnjenjima. Ministarstvo gospodarstva, poduzetništva i obrta. Dostupno na: https://e-obrt.minpo.hr/ [20.9.2017].

Pohl, G., Anderson, R. E., Claessens S., Djankov, S. (1997) Privatization and Restructuring in Central and Eastern Europe: Evidence and Policy Options. Technical Paper 368, Washington, D.C.: The World Bank.

Smith, S. C., Beom-Cheol, C., Vodopivec, M. (1997) Privatization Incidence, Ownership Forms, and Firm Performance: Evidence from Slovenia. Journal of Comparative Economics, 25 (Article No.JE971463): 158-179.

Šundalić, A. (2012) Između društva rada i društva znanja. Media, culture and public relations, 3 (2): 120130.

Veselica, V., Vojnić, D. (2000) Europske zemlje u tranziciji na pragu XXI. stoljeća: gdje je Hrvatska - Quo Vadis Croatia. Ekonomski pregled, 51 (9-10): 829 - 866.

Zinnes, C., Eilat Y., Sachs, J. (2001) The Gains from Privatization in Transition Economies: Is "Change of Ownership" Enough? IMF Staff Papers, 48: 146-170. Transition Economies: How Much Progress? International Monetary Fund, Palgrave Macmillan Journals. 
